\title{
Biopsy and Active Surveillance in Small Renal Masses
}

\author{
Turgay Turan* and Turhan Caskurlu \\ Department of Urology, Istanbul Medeniyet University, Turkey
}

Submission: February 19, 2017; Published: March 24, 2017

*Corresponding author: Turgay Turan, Department of Urology, Istanbul Medeniyet University, Turkey, Email: tcaskurlu@hotmail.com

\begin{abstract}
Small renal masses are masses that have been determined by axial imaging methods to be $\leq 4 \mathrm{~cm}$ in diameter. The treatments that can be used for these masses are active surveillance (AS), ablative therapy, or partial or radical nephrectomy. A renal tumor biopsy is an accurate and safe way to employ AS and gain information about the prognoses of small renal masses. The biopsy can be performed using ultrasonography or computed to mography guidance, which are called core biopsies and fine-needle aspiration biopsies.
\end{abstract}

Keywords: Active Surveillance; Renal biopsy; Small renal mass

Abbreviations: SRM: Small Renal Mass; As: Active Surveillance; RTB: Renal Tumor Biopsy

\section{Introduction}

There has been an increase in the diagnosis of small renal masses (SRMs) as renal cell carcinoma, and this increase seems to be linked to the widespread utilization of abdominal imaging. The treatments that can be used for these masses are active surveillance (AS), ablative therapy or partial or radical nephrectomy. The main objective of these treatments is to attain a successful oncological outcome and maximum renal function protection. In addition, overtreatment should be avoided due to its potential for morbidity. In this mini-review, the roles of the biopsy and AS of SRMs are explained.

\section{Biopsy and Surveillance}

SRMs are masses that have been determined by axial imaging methods to be $\leq 4 \mathrm{~cm}$ in diameter. Surgical intervention, which generally occurs soon after the diagnosis of SRMs, provides adequate information about the nature of the disease [1] observed benign lesions in 221 patients (23\%) after the surgery of $4 \mathrm{~cm}$ masses [2] concluded that the risk of metastasis in SRMs up to $4 \mathrm{~cm}$ large was $2 \%$. Other published studies have shown that AS does not have negative effects on cancer-specific survival and overall survival $[3,4]$.

The axial imaging methods are insufficient to divide the histological types of renal masses except angiomyolipomas. The European Association of Urology guidelines [5] on renal cell carcinoma (RCC) recommended the use of a renal tumor biopsy (RTB) before ablative therapy and systemic therapy without previous pathology (Grade of recommendation: C). Over 13 years [6] studied 509 patients who had SRMs up to $4 \mathrm{~cm}$ large. According to this study, peri-renal hematomas were seen in $4.7 \%$ of patients, bleeding through the coaxial sheath was observed in $2.4 \%$ of patients and self-limited gross hematuria was observed in only $1 \%$ of patients. Percutaneous angioembolization was required for the patient who had a peri-renal hematoma. In the same study, 131 patients (26\%) had a benign histology. In this study, the RTB of SRMs showed a high rate of diagnostic accuracy, and more than a quarter of tumors were observed as benign [7] published a study on 301 consecutive cases of percutaneous needle core biopsy (NCB). In this study, $23 \%$ of patients' tumors were benign. NCBs were used to confirm diagnoses confirmed in $89 \%$ of the renal included in this study, and renal mass NCBs were $93 \%$ accurate in the determination of the histologic subtypes of renal carcinoma. After radical nephrectomy, the diagnoses of primary renal malignancy in all 55 patients were $100 \%$ accurate, and only the diagnoses of the RCC subtypes of 4 patients were inaccurate. Therefore, percutaneous NCB plays a significant role in the definite tissue diagnosis of renal masses before treatment and in the guidance of patient management.

In an analysis of 57 studies, [8] investigated 5,228 patients. In this study, diagnostic core biopsy and fine-needle aspiration (FNA) results were compared. The overall median diagnostic rate of RTB was $92 \%$. The sensitivity and specificity of the diagnostic core biopsies were $99.1 \%$ and $99.7 \%$, respectively and the sensitivity and specificity of the FNAs were $93.2 \%$ and $89.8 \%$, respectively. A very low rate of Clavien complications $\geq 2$ 
was observed. Therefore, RTB is conclusively safe and has a high diagnostic efficiency in experienced centers.

Biopsy can be performed using ultrasonography or computed tomography guidance, which are used for core biopsies and FNA biopsies. For solid masses, core biopsies are preferable. At least two cores should be sampled during renal mass biopsy. Due to the risk of central necrosis, peripheral sampling should be done. Needles 18G or larger should be used for the core biopsy of renal masses to produce a high diagnostic yield. A coaxial biopsy cannula has been suggested as a method to create biopsy efficiency by preventing tumor seeding and taking various amounts of tissue samples [9].

In a prospective study [10], either adapted AS to patients who had SRMs up to $4 \mathrm{~cm}$ large or treated them immediately. Of the 221 patients in the surveillance group, 21 received delayed interventions. In the AS group, old patients who had bad Eastern Cooperative Oncology Group scores, and cardiovascular comorbidities had multiple and bilateral lesions. As a result of long-term follow-up periods, AS was determined not to be inferior to primary intervention.

AS is recommended for elderly patients or co-morbid patients who have limited life expectancy and a high perioperative risk of surgical and medical complications [10]. The 2017 American Society of Clinical Oncology Clinical Practice guidelines [11] suggest the use of renal tumor biopsy if the result affects the guidance of the treatment of SRMs. AS is accepted as an initial management option for patients who have relevant comorbidities and limited life expectancy [12].

\section{Conclusion}

RTB is an accurate and safe method that can be used to recommend AS and gain information about the prognoses of SRMs. RTB has a high diagnostic yield in experienced centers. Therefore, patients who are planned AS for SRMs should be referred to experienced centers for a renal biopsy.

\section{References}

1. Frank I, Blute ML, Cheville JC, Lohse CM, Weaver AL, et al. (2003) Solid renal tumors: an analysis of pathological features related to tumor size. J Urol 70(6 Pt 1): 2217-2220.

2. Thompson RH, Hill JR, Babayev Y, Cronin A, Kaag M, et al. (2009) Metastatic renal cell carcinoma risk according to tumor size. J Urol 182(1): 41-45.

3. Ahmad AE, Finelli A, Jewett MA (2016) Surveillance of Small Renal Masses. Urology 98: 8-13.

4. Smaldone MC, Kutikov A, Egleston BL, Canter DJ, Viterbo R, et al. (2012) Small renal masses progressing to metastases under active surveillance: a systematic review and pooled analysis. Cancer 118(4): 997-1006.

5. Ljungberg B, Bensalah K, Bex A, Canfield S, Giles RH, et al. (2014) EAU guidelines on Renal Cell Carcinoma. European Association of Urology, Europe.

6. Richard PO, Jewett MA, Bhatt JR, Kachura JR, Evans AJ, et al. (2015) Renal tumor biopsy for small renal masses. Eur Urol 68(6): 1007-1013.

7. Hu R, Montemayor-Garcia C, Das K (2015) Role of percutaneous needle core biopsy in diagnosis and clinical management of renal masses. Hum Pathol 46(4): 570-576.

8. Marconi L, Dabestani S, Lam TB, Hofmann F, Stewart F, et al. (2016) Systematic review and meta-analysis of diagnostic accuracy of percutaneous renal tumour biopsy. EurUrol 69(4) 660-673.

9. Tsivian M, Rampersaud EN, Laguna Pes MP, Joniau S, Leveillee RJ (2013) Small renal mass biopsy-how, what and when: report from an international consensus panel. BJU Int 113(6): 854-863.

10. Pierorazio PM, Johnson MH, Ball MW, Gorin MA, Trock BJ, et al. (2015) Five-year Analysis of a Multiinstitutional Prospective Clinical Trial of Delayed Intervention and Surveillance for Small Renal Masses: The DISSRM Registry. EurUrol 68(3): 2-9.

11. Finelli A, Ismaila N, Bro B, Durack J, Eggener S, etal. (2107) Management of Small Renal Masses: American Society of Clinical Oncology Clinical Practice Guideline. J ClinOncol 17: JC02016699645.

12. Finelli A,Jewett MA (2016) Surveillance of Small Renal Masses. Urology 98(1) 8-13.

\section{Your next submission with Juniper Publishers} will reach you the below assets

- Quality Editorial service

- Swift Peer Review

- Reprints availability

- E-prints Service

- Manuscript Podcast for convenient understanding

- Global attainment for your research

- Manuscript accessibility in different formats

( Pdf, E-pub, Full Text, Audio)

- Unceasing customer service

Track the below URL for one-step submission https://juniperpublishers.com/online-submission.php 